\title{
Why Are There So Few Investor-State Arbitrations in China? A Comparison with Other East Asian Economies
}

Dae Un Hong ${ }^{*} \&$ Ju Yoen Lee ${ }^{* *}$

It is not easy to detect East Asia's presence in the field of investor-state dispute settlement (ISDS), despite its large economy. In addition to having less active foreign direct investment (FDI) relative to GDP and fewer investment treaties, East Asian economies and societies seem to possess certain characteristics that have contributed collectively to the dearth of ISDS cases in East Asia. Examples are the short history of international arbitration, the avoidance of litigation, the high proportion of state-owned enterprises in outward FDI from China, and the concentration of FDI in industries in which investor-state disputes are less likely to occur. This trend, however, is likely to change gradually with the ongoing socioeconomic changes in the region, including the increase in both outward and inward $F D I$, the increasing number of investment treaties, the growing familiarity with international (investment) arbitration among legal experts, the diversification of FDI, and the decreasing fear of administrative litigation.

Keywords: Investor-state Arbitration, East Asia, Foreign Direct Investment, Investment Treaty, Administrative Litigation.

* JSD candidate, Cornell University Law School; Attorney-at-Law (Korea Bar). A.B.(Seoul Nat'l Univ.), J.D.(Hanyang Univ.), LL.M.(Northwestern). ORCID: https://orcid.org/0000-0002-89700497. The author may be contacted at: dh632@cornell.edu / Address: Cornell Law School Myron Taylor Hall, Ithaca, NY 14853 USA.

** Visiting Scholar at Cornell University Law School; Attorney-at-Law (Korea Bar; Partner at Jinsol LLC). LL.B.(Korea Univ.), LL.M.(Peking / Northwestern), Ph.D.(Hanyang Univ.). ORCID: https://orcid.org/0000-0002-0190-0030. The author may be contacted at: jl3435@cornell.edu / Address: Cornell Law School, Myron Taylor Hall, Ithaca, NY 14853 USA. 


\section{INTRODUCTION}

Numerous foreign investors have been interested in the Chinese market ${ }^{1}$ since its opening in 1978. To attract foreign investment, China has signed many investment treaties with other countries. Since the International Centre for Settlement of Investment Disputes ("ICSID") Convention entered into force in China on February 6, 1993, Chinese outward investment has attracted a lot of attention. In this regard, one may assume that many investment arbitrations would have been brought by foreign investors against China or by Chinese investors against other countries. Neither is true, however, despite its large economy (Table 1). Although the total number of known investor-state dispute settlement ("ISDS") cases has continued to grow, reaching 817 as of July $31,2017,{ }^{2}$ China has been the respondent state in only three cases, and Chinese investors have initiated ISDS cases only five times.

Table 1: Population and Gross Domestic Product (GDP) of East Asia

\begin{tabular}{c|r|r}
\hline & Population (in thousands, 2016) & GDP (USD billion, 2016) \\
\hline China & $\mathbf{1 , 4 0 3 , 5 0 0 . 4 ( 1 8 . 8 \% )}$ & $\mathbf{1 1 , 3 8 2 ( 1 4 . 9 \% )}$ \\
\hline Japan & $127,748.5(1.7 \%)$ & $4,920(6.4 \%)$ \\
\hline Korea & $50,791.9(0.7 \%)$ & $1,393(1.8 \%)$ \\
\hline Taiwan & $23,556.7(0.3 \%)$ & $529(0.7 \%)$ \\
\hline Hong Kong & $7,302.8(0.1 \%)$ & $321(0.4 \%)$ \\
\hline Macau & $612.2(0.0 \%)$ & $46(0.1 \%)$ \\
\hline East Asia & $1,613,512.5(21.6 \%)$ & $18,590(24.3 \%)$ \\
\hline World & $\mathbf{7 , 4 6 6 , 9 6 4 . 3}$ & $\mathbf{7 6 , 3 4 9}$ \\
\hline
\end{tabular}

Sources: UNCTAD STAT ${ }^{3}$

This phenomenon is not restricted to mainland China; its customs areas such as Hong Kong, ${ }^{4}$ Macao, and Taiwan and other East Asian economies such as Japan and Korea ${ }^{5}$ show similar situations. ${ }^{6}$ Even though China became the world's largest recipient of foreign direct investment ("FDI") inflow in 2014, it is not often addressed in the field of ISDS. More broadly, East Asia accounted for 17.8 percent of the worldwide FDI outflow stock in 2016, second only to Western Europe and North America (Table 2), but investors have been based in this region 
in only twelve known ISDS cases (1.3\%). Far more claimants have come from the rest of Asia, Eastern Europe, Latin America and the Caribbean, and Africa, although these regions account for only 6.1 percent, 1.6 percent, 2.1 percent, and 1 percent of the global FDI outflow, respectively.

Table 2: Number of ISDS Cases by Home Region of Investors (As of July 31, 2017)

\begin{tabular}{c|r|r|r}
\hline Regions & \multicolumn{1}{|c|}{ Cases } & $\begin{array}{c}\text { Outward FDI } \\
\text { Stock } \\
\text { (USD trillion) }\end{array}$ & $\begin{array}{c}\text { Cases per Outward } \\
\text { FDI Stock } \\
\text { (per USD trillion) }\end{array}$ \\
\hline Western Europe & $503(56.3 \%)$ & $11.41(41.9 \%)$ & 44.1 \\
\hline North America & $197(22.1 \%)$ & $7.60(27.9 \%)$ & 25.9 \\
\hline Asia, excluding East Asia & $80(9.0 \%)$ & $1.66(6.1 \%)$ & 48.1 \\
\hline Eastern Europe & $53(5.9 \%)$ & $0.44(1.6 \%)$ & 119.6 \\
\hline $\begin{array}{c}\text { Latin America and the } \\
\text { Caribbean }\end{array}$ & $31(3.5 \%)$ & $0.57(2.1 \%)$ & 54.4 \\
\hline Africa & $14(1.6 \%)$ & $0.27(1.0 \%)$ & 2.5 \\
\hline East Asia & $12(1.3 \%)$ & $4.84(17.8 \%)$ & 7.0 \\
\hline Oceania & $3(0.3 \%)$ & $0.43(1.6 \%)$ & 39.3 \\
\hline World outside of East Asia & $881(98.7 \%)$ & $22.39(82.2 \%)$ & \\
\hline
\end{tabular}

Sources: Compiled from UNCTAD Investment Dispute Settlement Navigator ${ }^{8}$ (cases) and UNCTAD STAT $^{9}$ (FDI stock)

The same applies to FDI inflow. Although East Asia accounts for 12.4 percent of the global FDI inflow stock as of 2016, again second only to Western Europe and the US (Table 3), East Asian economies have been respondents in ISDS cases only seven times ( 0.9 percent) - two times per USD 1 trillion in FDI inflow stock. The rate is far lower than the world average when East Asia is excluded (33.3 times) and lower than the average in Western Europe (6.8 times) and North America (5.7 times), where the rule of law is relatively more established and thus regulations are supposed to be less often imposed in an arbitrary manner.

Table 3: Number of ISDS Cases by Respondents (As of July 31, 2017)

\begin{tabular}{c|c|c|c}
\hline Regions & Cases & $\begin{array}{c}\text { Inward FDI Stock } \\
\text { (USD trillion) }\end{array}$ & $\begin{array}{c}\text { Cases per Inward FDI Stock } \\
\text { (per USD trillion) }\end{array}$ \\
\hline $\begin{array}{c}\text { Latin America } \\
\text { and the Caribbean }\end{array}$ & $228(27.9 \%)$ & $2.01(7.2 \%)$ & 113.6 \\
\hline
\end{tabular}




\begin{tabular}{c|r|r|r}
\hline Eastern Europe & $216(26.4 \%)$ & $1.12(4.0 \%)$ & 192.2 \\
\hline $\begin{array}{c}\text { Asia, excluding } \\
\text { East Asia }\end{array}$ & $169(20.7 \%)$ & $3.36(12.1 \%)$ & 49.4 \\
\hline Africa & $92(11.3 \%)$ & $0.84(3.0 \%)$ & 110.0 \\
\hline Western Europe & $61(7.5 \%)$ & $8.99(32.4 \%)$ & 6.8 \\
\hline North America & $42(5.1 \%)$ & $7.35(26.5 \%)$ & 5.7 \\
\hline East Asia & $7(0.9 \%)$ & $3.42(12.3 \%)$ & 2.0 \\
\hline Oceania & $2(0.2 \%)$ & $0.67(2.4 \%)$ & 3.0 \\
\hline $\begin{array}{c}\text { World outside of } \\
\text { East Asia }\end{array}$ & $810(99.1 \%)$ & $24.33(87.7 \%)$ & 33.3 \\
\hline
\end{tabular}

Sources: Compiled from UNCTAD Investment Dispute Settlement Navigator ${ }^{10}$ (cases) and UNCTAD STAT $^{11}$ (FDI stock)

In this research, the authors will try to explain why ISDS has been so rarely utilized in China and other East Asian economies despite their large economy. This article is composed of six parts including an introduction and conclusion. Part two will discuss general factors applicable to both outward and inward FDI. Parts three and four will discuss specific reasons for the dearth of ISDS cases initiated by Chinese and other East Asian investors or brought against China and other East Asian economies. Part five will touch on the signs of change in the future.

\section{Factors Applicable to Few ISDS Cases in BOTH OUTWARD AND INWARD FDI}

\section{A. Less Active FDI}

Outward FDI had been relatively inactive in China and other East Asian economies until recently. In 2005, the outward FDI stocks of China, Japan, and Korea accounted for less than 10 percent of their GDPs, far below the average of other economies (Table 4). Although their stocks continued to grow (and more than tripled in 2015), they are still well below the average of other economies. The same applies to the inward FDI stocks of China, Japan, and Korea. Although inward FDI stocks comprise a larger percentage of the GDP in China than in Japan and Korea, this percentage is still well below the average of the 
Organization for Economic Cooperation and Development (“OECD”) countries outside East Asia and the world average (excluding China, Japan, and Korea). The low outward and inward FDI activity of these economies has presumably contributed to less utilization of ISDS in East Asia.

Table 4: FDI Stocks as a Share of GDP

\begin{tabular}{c|r|r|r|r|r|r}
\hline & \multicolumn{3}{|c|}{$\begin{array}{c}\text { Outward FDI Stock as a } \\
\text { Share of GDP }\end{array}$} & \multicolumn{3}{c}{$\begin{array}{r}\text { Inward FDI Stock as a } \\
\text { Share of GDP }\end{array}$} \\
\hline Year & $\mathbf{2 0 0 5}$ & $\mathbf{2 0 1 0}$ & $\mathbf{2 0 1 5}$ & $\mathbf{2 0 0 5}$ & $\mathbf{2 0 1 0}$ & \multicolumn{1}{c}{$\mathbf{2 0 1 5}$} \\
\hline China & $2.8 \%$ & $5.2 \%$ & $10.0 \%$ & $20.6 \%$ & $25.7 \%$ & $24.5 \%$ \\
\hline Japan & $8.1 \%$ & $14.6 \%$ & $28.0 \%$ & $2.1 \%$ & $3.8 \%$ & $4.0 \%$ \\
\hline Korea & $4.3 \%$ & $13.2 \%$ & $20.7 \%$ & $11.7 \%$ & $12.4 \%$ & $13.0 \%$ \\
\hline $\begin{array}{c}\text { OECD, excluding Japan } \\
\text { and Korea }\end{array}$ & $31.7 \%$ & $41.8 \%$ & $44.4 \%$ & $27.0 \%$ & $33.6 \%$ & $40.1 \%$ \\
\hline $\begin{array}{c}\text { World, excluding China, } \\
\text { Japan, and Korea }\end{array}$ & $28.3 \%$ & $35.4 \%$ & $38.6 \%$ & $26.9 \%$ & $34.6 \%$ & $40.5 \%$ \\
\hline $\begin{array}{c}\text { Sources: Compiled by the authors from OECD.Stat } \\
\text { Sond UNCTAD STAT (FDI stock) }\end{array}$ \\
\hline
\end{tabular}

\section{B. Relatively Few Investment Treaties, ${ }^{14}$ Except in China and Korea}

According to the United Nations Conference on Trade and Development ("UNCTAD"), the total number of investment treaties in force reached 2,673 in 2017. ${ }^{15}$ Japan has been much less active in negotiating investment treaties than China and Korea, and Taiwan has faced difficulty negotiating treaties with other economies because of its special relationship with mainland China (Table 5). Currently, only twenty-three investment treaties are in force in Hong Kong despite its huge inward and outward FDI. Macau has only four investment treaties.

Table 5: Number of Investment Treaties in Force (As of July 31, 2017)

\begin{tabular}{c|c|r|r|r}
\hline Rank & Economy & \multicolumn{1}{|c|}{ BITs } & \multicolumn{1}{c}{ TIPs } & \multicolumn{1}{c}{ Total } \\
\hline 1 & Germany & 129 & 56 & 185 \\
\hline 2 & France & 96 & 56 & 152 \\
\hline 3 & United Kingdom & 95 & 56 & 151 \\
\hline 4 & Netherlands & 90 & 56 & 146 \\
\hline 5 & Switzerland & 112 & 31 & 143 \\
\hline 8 & China & 110 & 19 & 129 \\
\hline 21 & Korea & 88 & 17 & 105 \\
\hline
\end{tabular}




\begin{tabular}{r|c|r|r|r}
\hline 36 & Russia & 63 & 6 & 69 \\
\hline 51 & Canada & 35 & 17 & 52 \\
\hline 60 & Japan & 24 & 19 & 43 \\
\hline 102 & Taiwan & 17 & 6 & 23 \\
\hline 102 & Hong Kong & 18 & 5 & 23 \\
\hline 135 & Brazil & 0 & 13 & 13 \\
\hline 179 & Macau & 2 & 2 & 4 \\
\hline
\end{tabular}

Source: UNCTAD International Investment Agreements Navigator ${ }^{16}$

The small number of investment treaties may help to explain why there have been so few ISDS cases brought from or against Hong Kong, Macau, Taiwan, and Japan; fewer investment treaties will generally lead to less protection of investors and, therefore, a small number of ISDS cases. For example, because Brazil did not sign the ICSID Convention and has no bilateral investment treaty ("BIT") in force, ${ }^{17}$ no ISDS case has been initiated by Brazilian investors or brought against the Brazilian government. ${ }^{18}$ This explanation, however, has obvious limitations for the cases of China and Korea. For example, Canada and Russia have far fewer investment treaties than China and Korea (Table 5), but they have each appeared in ISDS cases more frequently than all East Asian economies combined. Whereas twelve ISDS cases have been initiated by East Asian investors and seven have been brought against East Asian economies, Canadian and Russian investors have initiated forty-five and sixteen ISDS cases, and twenty-six and twenty-four cases have been brought against Canada and Russia, respectively. ${ }^{19}$

It is also worth noting that China's early BITs did not include an investorstate dispute option in line with the treaty practice at that time. ${ }^{20}$ These BITs tended to define investments narrowly and would only grant foreign investors most-favored-nation treatment. ${ }^{21}$ It was not until the late 1990s that Chinese BITs started providing access to ICSID for all kinds of investor-state disputes. ${ }^{22}$ In addition, when China became a contracting party of the ICSID Convention, it made a reservation that it "would only consider submitting to the jurisdiction of the ICSID disputes over compensation resulting from expropriation or nationalization." 23 This practice would have been an obstacle to ISDS claims, although foreign investments in China, especially infrastructure investments, have frequently become subject to forcible takeovers in the name of 'public interest' as an alternative to expropriation. ${ }^{24}$ 


\section{Factors Applicable to Few ISDS Cases in OUTWARD FDI: Characteristics OF ChINESE AND OTher EAST ASIAN INVESTORS}

\section{A. Characteristics of East Asian Economies as the Home States of Claimants}

\section{Unfamiliarity with Arbitration among Legal Experts}

The rarity of ISDS cases in China and other East Asian economies is partly attributable to a lack of familiarity with the arbitration system in the region. International arbitration as we know it today developed mainly in the West, especially in Europe, ${ }^{25}$ and it is still not widely used in East Asia. The history of modern arbitration is relatively short in China as the Arbitration Act was first enacted in 1994 and came into force in $1995 .^{26}$ Although each year approximately 700 cases are filed with the China International Economic and Trade Arbitration Commission, most of which are not domestic but international. ${ }^{27}$ Arbitration acts were enacted earlier in other economies: first in Japan in 1890 as a part of the Code of Civil Procedure Act ${ }^{28}$ and then in Korea in 1965. Nevertheless, business disputes, especially domestic ones, are still rarely brought to arbitration in Japan ${ }^{29}$ and Korea. ${ }^{30}$ The lack of confidence in the integrity of the arbitration process is a persistent problem in Taiwan, as well. ${ }^{31}$

In China, because no legal education system existed during the Cultural Revolution (the national bar exam was first implemented in 2002), lawyers have not had enough time to develop extensive experience in international litigation or arbitration. In Japan and Korea, the legal market has generally been dominated by a small number of judicial elites ${ }^{32}$ who are not very interested in international litigation or arbitration. Actually, most major Japanese and Korean law firms did not begin to establish overseas offices until recently, which helps to explain how much they lag behind their Western counterparts in terms of globalization. ${ }^{33}$ As a result, there are far fewer arbitrators or arbitration experts in East Asia than in other major developed or developing economies, such as the US, the UK, Argentina, Mexico, and Brazil. ${ }^{34}$ This situation has resulted in a lack of ISDS experts in the region. In fact, there were no arbitrators from either China or other East Asian economies in the ICSID cases until December $2010 .^{35}$ Of the 401 arbitrators, conciliators, and ad hoc committee members who participated in the 
ICSID cases as of the end of $2016,^{36}$ only four were from East Asia: one each from China (although he resigned during the proceedings), Hong Kong, Japan, and Korea. ${ }^{37}$

Consequently, the relatively short history of arbitration and the resulting lack of arbitration experts in East Asia have prevented many East Asian investors from utilizing ISDS.

\section{Avoidance of Litigation against the Government ${ }^{38}$}

International investment law deals with situations similar to those under domestic administrative law. ${ }^{39}$ It is widely agreed that East Asian technocrats have been less subjected to judicial interference than their American and European counterparts. Here, the administration has thus exercised greater power than other branches of society. ${ }^{40}$ In China, the Administration Litigation Law was not implemented until October 1990. Even now, taking local officials to court is still like "throwing an egg against a stone" for victims because administrative malfeasance would not be easily found to be illegal in Chinese courts. ${ }^{41}$ Considering that China is still dominated by a single party, it is no surprise that Chinese courts play a complementary role in political-administrative mechanisms for dispute resolution and an even more limited role in the making of key policies, particularly with respect to politically sensitive cases. ${ }^{42}$ Traditionally, in Japan, the administration has been more active than the court, ${ }^{43}$ so that it is difficult for plaintiffs to prevail in administrative litigation in Japan. ${ }^{44}$ Korea was subject to authoritarian regimes with an imperial presidency for decades until the 1980s through the de facto presumption of executive supremacy by the use of various law enforcement offices, such as the police, prosecutors' office, and intelligence office. ${ }^{45}$ Moreover, there are even legal obstacles to overcome, such as statutes of limitation, for administrative litigation in Japan and Korea. ${ }^{46}$ Similarly, although the Administrative Court and the Administrative Litigation Act had been effective for a long time in Taiwan, bureaucracy was only checked in a limited manner before 1987, when the Martial Law Decree was lifted and political liberalization began. Because many are still afraid to bring a claim against the state, administrative litigation has not been widely used in East Asia.

Table 6 shows that there exists a huge gap in administrative litigation between East Asia and many other regions. Although the amount of administrative 
litigation in China has increased remarkably, only 225,485 cases took place in 2016, which is a relatively small number given China's large population. In Korea, 30,834 administrative cases were filed in all courts in the same year. In Japan, a country with well over 100 million people, only 9,813 administrative litigations were initiated in 2016. In contrast, administrative litigation was much more popular in many other countries, such as France, Poland, and Sweden. In Spain, which is roughly comparable to Korea in terms of population and GDP, there were 191,088 administrative litigations in 2013. In Russia, 563,976 claims were brought against the government in 2011. The Brazilian government was sued in a total of 2,580,232 claims in courts of the first degree and 676,966 times in courts of the second degree in 2009.

Table 6: Number of Administrative Litigations per 1,000 People by Economy

\begin{tabular}{|c|c|c|c|c|}
\hline Regions & Year & $\begin{array}{c}\text { Administrative } \\
\text { Cases }\end{array}$ & Population & $\begin{array}{l}\text { Administrative Cases } \\
\text { per } 1,000 \text { People }\end{array}$ \\
\hline Brazil $^{48}$ & 2009 & $3,257,198$ & $194,895,996$ & 16.71 \\
\hline Sweden $^{49}$ & 2014 & 133,161 & $9,689,376$ & 13.74 \\
\hline Lithuania $^{50}$ & 2013 & 22,748 & $2,997,334$ & 7.59 \\
\hline Spain $^{51}$ & 2013 & 191,088 & $46,697,052$ & 4.09 \\
\hline Russia $^{52}$ & 2011 & 565,332 & $143,263,988$ & 3.95 \\
\hline France $^{53}$ & 2014 & 237,564 & $66,418,986$ & 3.58 \\
\hline Poland $^{54}$ & 2015 & 102,165 & $38,265,226$ & 2.67 \\
\hline \multirow{2}{*}{ Taiwan $^{55}$} & 2016 & 25,741 & $23,556,706$ & 1.09 \\
\hline & 2012 & 12,064 & $22,928,526$ & 0.53 \\
\hline \multirow{2}{*}{ Macau $^{56}$} & 2016 & 632 & 612,167 & 1.03 \\
\hline & 2008 & 219 & 514,348 & 0.43 \\
\hline \multirow{2}{*}{ Korea $^{57}$} & 2016 & 30,834 & $50,791,919$ & 0.61 \\
\hline & 2008 & 23,389 & $49,218,985$ & 0.48 \\
\hline \multirow{2}{*}{ China $^{58}$} & 2016 & 225,485 & $1,403,500,365$ & 0.16 \\
\hline & 2008 & 108,398 & $1,344,415,227$ & 0.08 \\
\hline \multirow{2}{*}{ Japan $^{59}$} & 2016 & 9,813 & $127,748,513$ & 0.08 \\
\hline & 2008 & 8,571 & $128,550,508$ & 0.07 \\
\hline Hong Kong $^{60}$ & 2012 & 159 & $7,106,399$ & 0.02 \\
\hline
\end{tabular}

Sources: UNCTAD STAT ${ }^{61}$ (population) 
Moreover, state-owned enterprises ("SOEs") account for a significant portion of the Chinese and Taiwanese economies. SOEs and entities directly controlled by SOEs comprise more than 40 percent of China's non-agricultural GDP. ${ }^{62}$ Including the contributions of indirectly controlled entities, urban collectives, and public township and village enterprises, approximately 50 percent of GDP is owned and controlled by the state. ${ }^{63}$ Taiwanese authorities control many SOEs in various sectors, as well. ${ }^{64}$ In general, SOEs are not likely to bring administrative action against the government because they are supposed to share many common interests with the government and generally act in alignment with it.

In short, limited experience with bringing a legal claim against the government has likely contributed to East Asian investors' hesitation to initiate an ISDS case.

\section{Legal Culture}

In many aspects, Confucian societies such as China, Japan, and Korea demonstrated a preference for resolving interpersonal conflicts outside the court. ${ }^{65}$ Legal sanctions were used only when no alternative existed or the gains were thought to outweigh the costs of compromised relations and trust. ${ }^{66}$ In general, informal mechanisms rather than formal legal rules were used to resolve most civil disputes. $^{67}$

Based on Confucianism, Chinese ${ }^{68}$ and Japanese ${ }^{69}$ societies are still reluctant to litigation. In a dispute about transnational energy pipelines, a Chinese scholar claimed that the best way to settle a dispute was through diplomatic or political means, such as negotiation and consultation, and that legal methods should always be a last resort. ${ }^{70}$ In general, Japanese investors are risk-averse and prefer to take a long-term view when disputes arise. Therefore, they have not yet directly availed themselves of the ISDS provisions provided in any Japanese treaty, even those with developing countries. ${ }^{71}$ Japanese investors tend to negotiate amicable settlements directly with the host state or through the informal good offices of their own government. ${ }^{72}$

In brief, the traditional Confucian preference for amicable resolution ${ }^{73}$ of disputes through moral persuasion rather than legal processes in China, Japan, and Korea $^{74}$ appears to be an important factor affecting the number of ISDS cases.

\section{High Portion of SOEs in Outward FDI from China}

According to the People's Republic of China ("PRC") Ministry of Commerce, 
outward FDI from China's SOEs accounted for 69.2 percent of total outward FDI stock at the end of 2009, whereas private firms accounted for only 1 percent of total outward FDI stock. ${ }^{75}$ In addition, all the top thirty firms, ranked by overseas assets and overall firm size, are SOEs. ${ }^{76}$ The proportion of SOEs involved in outward FDI is estimated to be higher if other types of companies under the Chinese government's influence are included. ${ }^{77}$

Chinese investors have emerged from a strongly state-led economic model featuring a high level of state ownership in national enterprises. ${ }^{78}$ As China's corporate engagement is based on its diplomatic strategy, ${ }^{79}$ SOEs may be discouraged from initiating an ISDS claim due to the diplomatic concerns of their home state, although Beijing's control mechanism may not always be direct or effective. ${ }^{80}$ For example, China relies heavily on the coordination of a complex array of corporations and government bureaucracies to achieve its policy objectives in Africa. ${ }^{81}$ Moreover, a conventional moral hazard problem may prevent Chinese SOEs from initiating ISDS cases. They may feel free to act in a fiscally irresponsible manner by relying on China's state-controlled banks for financial support regardless of their economic performance. ${ }^{82}$ In China, because SOEs are the primary source of outward FDI, Chinese investors initiate few ISDS claims.

\section{Concentration of Outward FDI in the Japanese, Korean, and Taiwanese}

\section{Manufacturing Industries}

Industry-specific analysis is appropriate because investor-state disputes are more likely to occur in some industries (e.g., oil exploration) than in others (e.g., light industry). ${ }^{83}$ For instance, it is hardly expected that a foreign investor in a T-shirt factory would be concerned about the kind of mistreatment of investors unambiguously outlawed by BITs. ${ }^{84}$ Indeed, of the 648 cases in which the economic sector was identified by ICSID on December 10, 2017, investor-state disputes were most frequent (23.8 percent) in the oil, gas, and mining sectors, followed by the energy sector (Figure 1). Manufacturing is one of the least litigated industries in ISDS and belongs to other industry. 
Figure 1: ICSID Cases by Economic Sector (As of July 31, 2017)

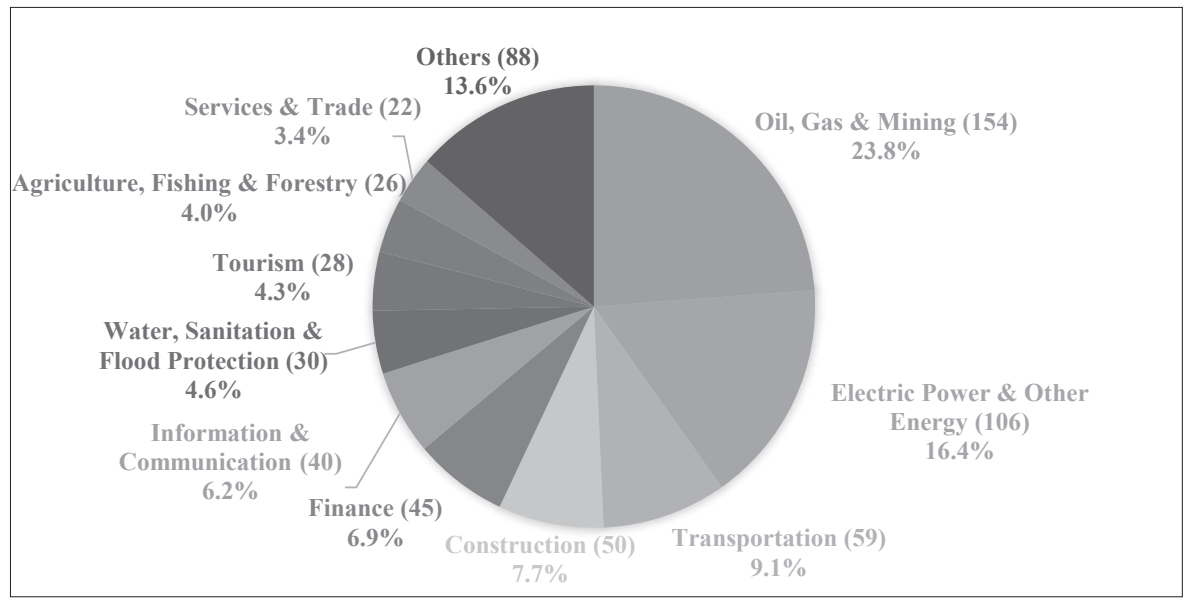

Source: $\operatorname{ICSID}^{85}$

East Asia has highly manufacturing-oriented economies. The percentage of the GDP produced by the manufacturing industries in China (incl. Taiwan) and Korea is higher than double the average in non-East Asian economies (Table 7).

Table 7: Manufacturing as a Share of GDP

\begin{tabular}{r|r|r|r|r}
\hline Taiwan (2016) & Korea (2015) & China (2015) & Japan (2015) & $\begin{array}{l}\text { World outside of } \\
\text { East Asia (2015) }\end{array}$ \\
\hline $30.3 \%$ & $29.8 \%$ & $29.4 \%$ & $20.5 \%$ & $13.4 \%$ \\
\hline
\end{tabular}

Sources: Compiled from World Bank (China, Japan, Korea, and world) ${ }^{86}$ and Statista.com (Taiwan) $^{87}$

This economic structure has resulted in an unusually high degree of concentration of outward FDI in manufacturing, at least among the OECD members, although the degree of concentration has decreased in recent years (Figure 2). The same applies to Taiwan. By the end of 1995, 65.9 percent of Taiwanese outward investments were directed at manufacturing activities, ${ }^{88}$ and manufacturing was the target industry of about half of Taiwan's outward investment flow in 2013 . $^{89}$ 
Figure 2: Portion of Outward FDI Stocks in the Manufacturing Industry

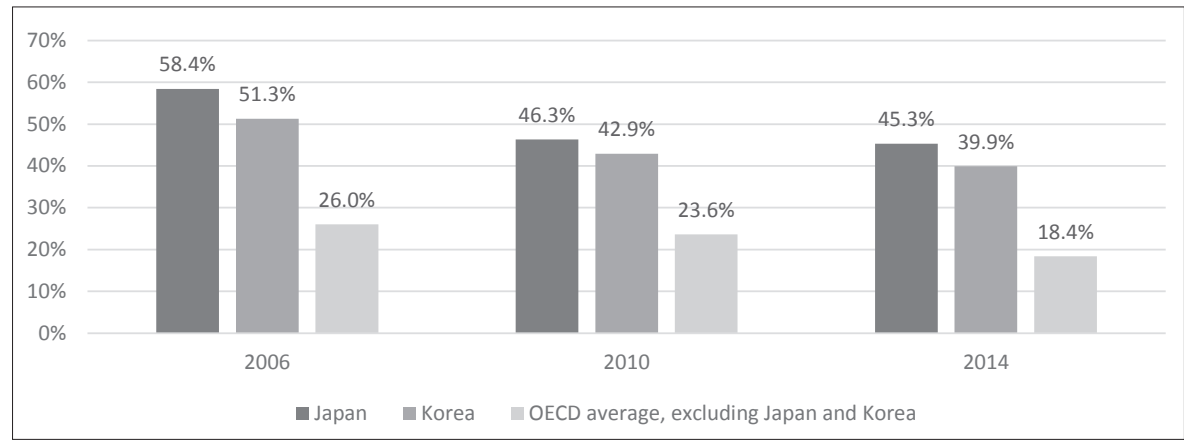

Source: Compiled from OECD.Stat ${ }^{90}$

To sum up, outward FDI from Japan, Korea, and Taiwan is concentrated not in the resource extraction and energy sectors (where ISDS is most frequently used) but in the manufacturing industry (where ISDS is very rarely used). This seems to have contributed to the dearth of ISDS cases initiated by investors from those economies.

\section{Factors Applicable to Few ISDS Cases IN INWARD FDI: WhO INVESTS IN EAST ASIA, AND Where Do They InVest?}

As mentioned above in Table 3, East Asian economies have been respondents in ISDS cases far less often than other economies, including their counterparts in Western Europe and North America. What brought East Asia to this dearth of claims against their economies?

\section{A. Investments from East Asia}

The characteristics of East Asian economies, as discussed in Part III - unfamiliarity with arbitration, avoidance of litigation (against the government), and the predominance of investment in the manufacturing industry - are still applicable to inward investment because East Asian economies themselves are the primary sources of foreign investment in East Asia (Table 8). For example, FDI from Hong 
Kong accounted for 70 percent of China's inward FDI for a long period. ${ }^{91}$

Table 8: Intra-region FDI Stocks in East Asia in 2012

\begin{tabular}{|c|c|c|c|}
\hline $\begin{array}{l}\text { Invested } \\
\text { Economy }\end{array}$ & Investing Economy & $\begin{array}{c}\text { Inward FDI Stock } \\
\text { from East Asia } \\
\text { (USD billion) }\end{array}$ & $\begin{array}{c}\text { Total Inward FDI } \\
\text { Stock } \\
\text { (USD billion) }\end{array}$ \\
\hline China & $\begin{array}{l}\text { Hong Kong }(44.1 \%) \text {, Japan } \\
(6.5 \%) \text {, Taiwan }(4.2 \%) \text {, Korea } \\
(3.9 \%) \text {, Macau }(0.8 \%)\end{array}$ & $799.8(59.5 \%)$ & $1,343.6$ \\
\hline Hong Kong & $\begin{array}{l}\text { China }(37.0 \%) \text {, Japan }(1.8 \%), \\
\text { Korea }(0.9 \%) \text {, Taiwan }(0.7 \%)\end{array}$ & $502.8(40.4 \%)$ & $1,244.6$ \\
\hline Macau & $\begin{array}{l}\text { Hong Kong }(25.9 \%) \text {, China } \\
(12.2 \%), \text { Japan }(0.2 \%), \text { Korea } \\
(0.1 \%)\end{array}$ & $7.3(38.3 \%)$ & 18.9 \\
\hline Korea & $\begin{array}{l}\text { Japan }(26.8 \%) \text {, Hong Kong } \\
(2.1 \%) \text {, China }(1.3 \%) \text {, Taiwan } \\
(0.2 \%)\end{array}$ & $47.4(30.4 \%)$ & 156.1 \\
\hline Taiwan & $\begin{array}{l}\text { Japan }(14.3 \%), \text { Hong Kong } \\
(5.0 \%) \text {, Korea }(0.8 \%)\end{array}$ & $24.3(20.0 \%)$ & 121.4 \\
\hline Japan & $\begin{array}{l}\text { Hong Kong }(2.8 \%), \text { Korea } \\
(1.4 \%) \text {, Taiwan }(1.2 \%) \text {, China } \\
(0.3 \%)\end{array}$ & $11.7(5.7 \%)$ & 205.8 \\
\hline Total & & $1,393.3(45.1 \%)$ & $3,090.5$ \\
\hline
\end{tabular}

Sources: Compiled from UNCTAD Bilateral FDI Statistics 2014, ${ }^{92}$ OECD.Stat, ${ }^{93}$ and UNCTAD STAT (FDI stock) ${ }^{94}$

In the case of China, "round-tripping" must be mentioned. In the past, it was a rather common practice for Chinese companies to set up so-called special purpose vehicles ("SPVs") abroad for reinvestment on the Chinese mainland. ${ }^{95}$ Before 2008, one of the main goals of Chinese round-trip investment structures was to utilize special FIE tax holidays. ${ }^{96}$ Although the 2008 reform of China's enterprise income tax system abolished this opportunity, "round-tripping" is still used to gain access to overseas financing and to avoid regulatory as well as practical problems with onshore listings. ${ }^{97}$ As a result, some speculate that inward FDI in China may be overstated by between 25 and 50 percent. ${ }^{98}$ Such high portion of intra-region FDI would thus prevent foreign investors in East Asia from bringing their claims to ISDS. 


\section{B. Investments from Outside of East Asia}

1. Concentration of Inward FDI in the Manufacturing Industry in China, Japan, Korea, and Taiwan

As mentioned above, investor-state disputes are most likely to occur in the resource extraction and energy sectors but have little likelihood of occurring in the manufacturing industry. FDI in the primary sector (mostly the extraction industry) has been quite sluggish in East Asia as a whole. Comparing the composition of FDI inflow into China to that of FDI inflow into other economies, foreigners invest in more the secondary sector (mostly manufacturing) than the primary sector in China. Indeed, China's mining industry received only 0.5 percent of the total inward FDI stock, far below that of many other economies (Table 9). The share is even lower in Japan and Korea. In comparison, the primary sector in Latin America and the Caribbean received 23 percent of FDI inflows in $2005,{ }^{99}$ and the primary sector accounted for nearly 50 percent of FDI inflows between 1996 and 2000 in twenty-four African economies. ${ }^{100}$

Table 9: Portion of FDI Stocks in the Mining Industry (2014)

\begin{tabular}{c|c|c|c}
\hline China $^{101}$ & Japan & Korea & OECD average, excluding Japan and Korea \\
\hline $0.5 \%$ & $0.03 \%$ & $0.03 \%$ & $7.3 \%$ \\
\hline
\end{tabular}

Source: Compiled from OECD.Stat (Japan, Korea, and other OECD economies) ${ }^{102}$

By contrast, 70 percent of the FDI in China was concentrated in the manufacturing field before $2002,{ }^{103}$ partly due to the supply of cheaper labor and the relatively lower cost of materials. ${ }^{104}$ Inward FDI is highly concentrated in the manufacturing industry in Japan and Korea as well (Table 10). In Taiwan, 61.5 percent of inward FDI flowed into the manufacturing industry in $2016 .{ }^{105}$

Table 10: Portion of Inward FDI Stocks in Manufacturing Industry (2014)

\begin{tabular}{c|c|c|c}
\hline China $^{106}$ & Japan & Korea & OECD average, excluding Japan and Korea \\
\hline $54.2 \%$ & $40.6 \%$ & $38.2 \%$ & $20.4 \%$ \\
\hline
\end{tabular}

Source: Compiled from OECD.Stat (Japan, Korea, and other OECD economies) ${ }^{108}$

Although China is rich in natural resources, it has either discouraged or banned 
foreign investment in many areas of the extraction industry. Since 1995, the Chinese government has promulgated the Catalog for Industry Guidance of Foreign Investment (hereinafter the Catalog), which addresses the primary source of control over the industries in which foreigners may invest. ${ }^{109}$ The Catalog is divided into three parts: (1) encouraged industry; (2) restricted industry; and (3) prohibited industry. ${ }^{110}$ For example, the 2011 Catalog restricted foreign investment in ten categories of mining and prohibited foreign investment in three categories of mining. ${ }^{111}$ Therefore, it is no coincidence that the three ISDS cases brought against China were outside the extraction industry (Table 11).

Table 11: ISDS Cases Brought Against China (As of July 31, 2017)

\begin{tabular}{l|l|l}
\hline \multicolumn{1}{c|}{ Name } & \multicolumn{1}{c|}{ Industry } & \multicolumn{1}{c}{ Status } \\
\hline $\begin{array}{l}\text { Hela Schwarz GmbH (Germany) v. People's } \\
\text { Republic of China (ICSID Case No. } \\
\text { ARB/17/19) }\end{array}$ & $\begin{array}{l}\text { Manufacturing } \\
\text { (food products) }\end{array}$ & Pending \\
\hline $\begin{array}{l}\text { Ansung Housing Co., Ltd. (Korea) v. } \\
\text { People's Republic of China (ICSID Case No. } \\
\text { ARB/14/25) }\end{array}$ & $\begin{array}{l}\text { Real estate } \\
\text { development }\end{array}$ & $\begin{array}{l}\text { Decided in favor } \\
\text { of State }\end{array}$ \\
\hline $\begin{array}{l}\text { Ekran Berhad (Malaysia) v. People's Republic } \\
\text { of China (ICSID Case No. ARB/11/15) }\end{array}$ & Construction & Settled \\
\hline
\end{tabular}

Source: $\operatorname{ICSID}^{112}$

Unlike those of China, the mining industries of Japan, Hong Kong, Korea, and Taiwan are not attractive to foreign investors. Because natural resources are scarce and labor costs are high in all of these countries, their mining industries do not play a significant role in their economies. Japan's mining sector did not account for more than 0.2 percent of the GDP during any year from 1994 to $2013 .{ }^{113}$ In Hong Kong, the primary industry, including the mining and quarrying sectors, accounted for 0.1 percent of the GDP from 2012 to $2016 .{ }^{114}$ In Korea, mining and quarrying activity accounted for just 0.2 percent of GDP in 2013 and $2014 .^{115}$ In Taiwan, the mining and quarrying sectors accounted for 0.1 percent of GDP in 2014. ${ }^{116}$

To sum up, the concentration of inward FDI in the manufacturing industry and lack of inward FDI in the resource extraction industry, where ISDS is most likely 
to be used, appear to have contributed to the dearth of ISDS cases brought against East Asian economies.

\section{Preference for Informal Dispute Settlement with the Chinese Government}

Not only Chinese individuals but even foreigners in China would generally see administrative litigation as hopeless, costly, and dangerous to their relationship with the government. ${ }^{117}$ Only a handful of foreign litigants have directly challenged the Chinese state in court, mainly in regard to patent or trademark litigation initiated by multinational companies. ${ }^{118}$ Conversely, these companies would regularly challenge government actions in the courts of the US, the EU and developing economies such as Mexico, Brazil, and India. ${ }^{119}$ For foreign companies in China, 'tread carefully' continues to be the mantra of lawyers and businesspersons alike.

Foreign investors in China - both from Asia and the West - have often relied on guanxi, special relationships with the relevant government agencies, to do business in China. ${ }^{121}$ They are often advised to hire local consultants who can provide information about the internal workings of the Chinese government. The local consultants, who are usually former government officials, may have guanxi that are useful in setting up and coordinating meetings. ${ }^{122}$ These local government relations staff will always want to resolve such disputes by negotiation, ${ }^{123}$ not through a legal process (e.g., administrative litigation or arbitration). Even a prominent foreign lawyer who has practiced in China for decades will strongly advocate for a non-confrontational resolution of disputes with government agencies. $^{124}$

\section{Signs of Change: Why We Are Likely to See More Investor-State Arbitrations in East ASIA In The Future?}

It will become increasingly easier for both East Asian investors and foreign investors in East Asia to invoke investment treaties. As mentioned above, since the late 1990s, Chinese BITs have provided access to ICSID for all kinds of investorstate disputes, not just those arising from expropriation. In addition, there has been 
competition among East Asian economies to sign more investment treaties. For instance, the Japanese government aims to increase more than double the number of its investment treaties by $2020 .^{125}$

On the claimants' side, it is likely that more East Asian investors will avail themselves of ISDS in the future for the following reasons. First, there have been fast and steady increases in outward FDI from East Asia, especially from China because its outward FDI stock grew by more than 1,800 percent from 2005 to 2015 (Table 12). This number is far above that of the EU (80.0\%) and the US (65.1 $\%$ ). Chinese companies have increased outward FDI because domestic markets have become increasingly competitive and saturated, especially after $2000{ }^{126}$ Such a trend is likely to continue for the foreseeable future because China's outward FDI stock still accounts for a far smaller portion of its GDP than the world average (Table 4). Outward FDI stock from the rest of East Asia has substantially grown as well, more than quadrupling from 2005 to 2015. In contrast, outward FDI stock from the rest of the world has grown only 88.9 percent during the same period.

Table 12: Outward FDI Stock Growth Rate (2005-15)

\begin{tabular}{|c|c|c|c|c|}
\hline Regions & 2005 & 2010 & 2015 & $\begin{array}{l}\text { Growth Rate } \\
(2005-2015)\end{array}$ \\
\hline China & 57.2 & 317.2 & $1,097.9$ & $1819.2 \%$ \\
\hline Hong Kong & 476.2 & 943.9 & $1,531.4$ & $221.6 \%$ \\
\hline Japan & 386.6 & 831.1 & $1,226.6$ & $217.3 \%$ \\
\hline Korea & 38.7 & 144.0 & 285.9 & $639.2 \%$ \\
\hline Macau & 0.5 & 0.5 & 3.1 & $536.1 \%$ \\
\hline Taiwan & 103.3 & 190.8 & 303.1 & $193.3 \%$ \\
\hline East Asia & $1,062.5$ & $2,427.6$ & $4,448.0$ & $318.6 \%$ \\
\hline European Union & $5,060.7$ & $9,138.9$ & $9,110.7$ & $80.0 \%$ \\
\hline United States & $3,638.0$ & $4,809.6$ & $6,005.7$ & $65.1 \%$ \\
\hline $\begin{array}{l}\text { World outside of } \\
\text { East Asia }\end{array}$ & $10,840.0$ & $18,511.6$ & $20,477.2$ & $88.9 \%$ \\
\hline
\end{tabular}

Source: Compiled from UNCTAD STAT ${ }^{127}$ 
Second, international (investment) arbitration is becoming a more viable option for East Asian investors. The Chinese and Korean arbitration communities are becoming increasingly familiar with the ICSID proceedings, ${ }^{128}$ as the Chinese and the Korean governments have been promoting international arbitration. For example, the Chinese government has increased its legal diplomacy efforts in Africa to promote joint dispute arbitration mechanisms by establishing the China Africa Joint Arbitration Centre. ${ }^{129}$ Meanwhile, the Korean government played a key role in establishing the Seoul International Dispute Resolution Center in 2013 and enacting the Arbitration Industry Promotion Act in 2016. As Chinese lawyers are becoming more professional, ${ }^{130}$ arbitration has been increasing steadily in China. ${ }^{131}$ The capacity of corporate legal departments in Japan and Korea is improving partly due to the emergence of staff members who are practicing lawyers. ${ }^{132}$ In addition, more international law scholars in this region are studying and teaching ISDS. For example, only two scholarly articles on ISDS were published in Korean academic journals in 2005, but the number jumped to sixteen in 2010 and has been more than twenty each year since 2012 (Figure 3). Moreover, it is now much easier than before for future lawyers in the region to obtain international arbitration experience, including ISDS, by participating in international competitions based in East Asia, such as Vis Moot (East), which started in $2004^{133}$ and FDI International Arbitration Moot Asia Pacific Regional Round, which started in $2009 .{ }^{134}$

Figure 3: Number of Academic Journal Articles on ISDS in Korea

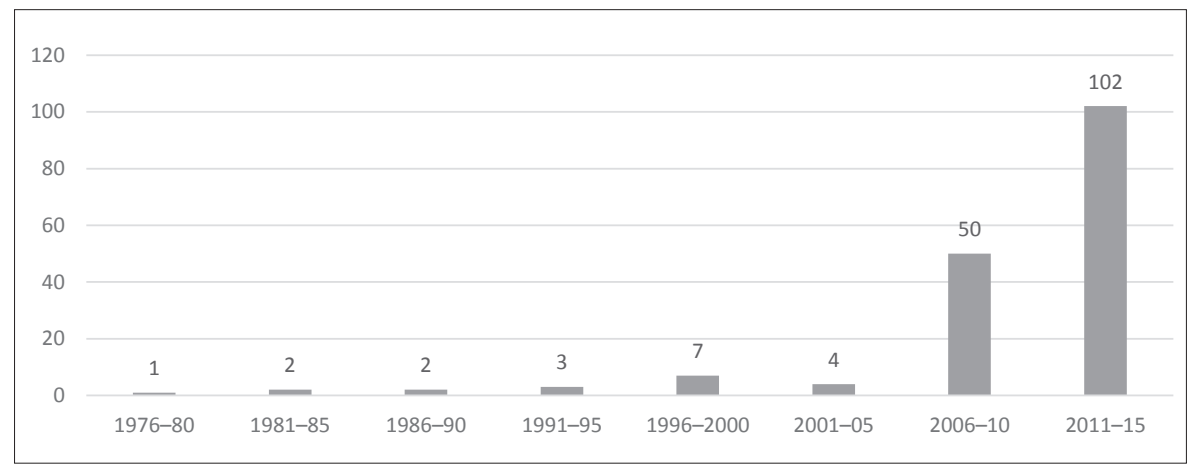

Source: Compiled from RISS ${ }^{135}$ 
Third, administrative litigation has been increasing in East Asia (Table 6). Compared to 2008, the number of administrative litigations per capita in 2016 increased by 99.3 percent in China. During the same period, this number went up to 15.2 percent in Japan, 27.7 percent in Korea, and 142.5 percent in Macau. In the case of Taiwan, the number of litigations has increased by 107.7 percent since 2012. This trend suggests that East Asian investors will be more willing to sue foreign governments in the future.

Fourth, the legal culture has been changing in this region. Today, Confucianism are weakening, while individualism is getting stronger among younger generations in China. ${ }^{136}$ The same applies to Japan, ${ }^{137}$ Korea ${ }^{138}$ Taiwan, ${ }^{139}$ and other East Asian societies although the degree of individualism may differ from region to region.

Fifth, SOEs in China held over 80 percent of total overseas investment stock in 2006 but only 55 percent in 2013. ${ }^{140}$ According to the MOFCOM, outbound investments by private enterprises would eventually surpass those by SOEs. ${ }^{141}$ This will likely result in more ISDS claims by Chinese investors because Chinese private companies will be less hesitant to resort to confrontational dispute resolution measures.

Sixth, outward FDI is becoming increasingly diversified and less concentrated in the manufacturing industry in Japan and Korea (Figure 2). This means that the more frequently ISDS is used, the more investments will be in these sectors.

On the respondent's side, more ISDS cases are likely to be brought against East Asia. First, the primary and energy sectors - where investor-state disputes are most likely to occur - in East Asia are increasingly open to foreign investment. China has recently decided to open many areas of the primary sector to foreign investors. For example, special administrative measures applied by the 2015 Catalog to exploration and development of unconventional oil and gas resources, such as oil shale, oil sands, and shale gas, were removed from the 2017 Catalog. ${ }^{142}$ In the energy sector, China relocated "construction and operation of power grids" from the restricted category to the encouraged one. Several types of power plants have also become a part of the encouraged category in the 2015 Catalog. ${ }^{143}$ In addition, the 1994 Energy Charter Treaty (hereinafter 1994 ECT), the most frequently invoked treaty in ISDS cases, ${ }^{144}$ has been expanding to East Asia. ${ }^{145}$ Although Japan is the only East Asian member country of the 1994 ECT, China and Korea signed the 2015 International Energy Charter, a nonbinding set of 
principles for international energy cooperation that was intended as the first step toward accession to the legally binding 1994 ECT. ${ }^{146}$ Moreover, Japan's electricity and gas markets were liberalized in 2016 and 2017, respectively, decades behind efforts in the EU and the US. ${ }^{147}$

Second, inward FDI in East Asia is becoming increasingly diversified, in accordance with fundamental changes in the economic structure of the region. International experience has demonstrated that the services sector becomes more attractive to foreign investment as an economy matures. ${ }^{148}$ Today's East Asia has the limited potential for further growth of the manufacturing sector. ${ }^{149}$ Moreover, there is a general perception that a weak service sector is less productive than a strong, internationally competitive manufacturing sector. ${ }^{150}$ China's service sector is lagging behind that of other economies at a similar stage of development. ${ }^{151}$ FDI in China is moving away from low-cost processing sectors to more value-added services. ${ }^{152}$ The year 2015 marked the third consecutive year of this trend, with 61.1 percent of total inward FDI going to the service sector. ${ }^{153}$ As a result, the portion of FDI stock in the manufacturing industry has been steadily declining in recent years (Figure 4). This trend is likely to continue as Chinese policies attempt to direct more investment to the service sector. ${ }^{154}$ Similar situations have been observed in other East Asian regions. The share of the service sector in the market has been steadily increasing in Japan. ${ }^{155}$ In Korea, there has been a recent shift toward the service industry, which still has great potential for development. ${ }^{156}$ In Taiwan, industrial production declined from more than 50 percent in 1986 to 24.78 percent in 2009 of GDP. ${ }^{157}$

\section{Figure 4: Portion of Inward FDI Stocks in China's Manufacturing Industry}

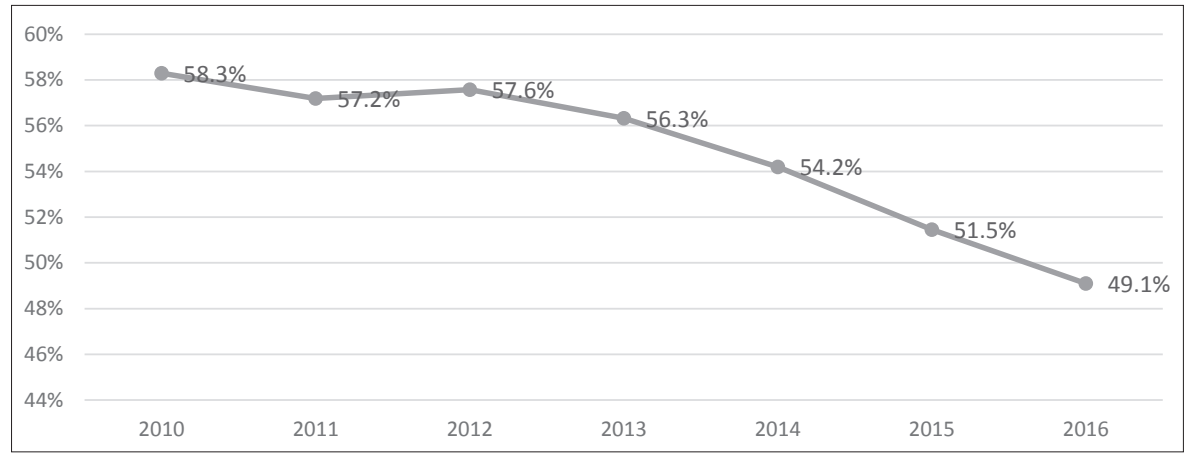

Source: MOFCOM ${ }^{158}$ 


\section{Conclusion}

To conclude, many of the characteristics of East Asia have contributed to the dearth of ISDS cases. These factors, however, are changing, although the degree of change may differ from region to region. The differences between East Asian and international investors appear to be decreasing, as are differences in the industry structure between East Asia and many other parts of the world. This trend will lead Chinese and other East Asian economies to use ISDS more in in the future.

\section{REFERENCES}

1. 'China' generally refers to mainland China in this paper.

2. UNCTAD, Investment Dispute Settlement Navigator, available at http:// investmentpolicyhub.unctad.org/ISDS (last visited on Feb. 6, 2018).

3. UNCTAD, Unctad Stat, available at http://unctadstat.unctad.org/wds/TableViewer/ tableView.aspx?ReportId=97; http://unctadstat.unctad.org/wds/TableViewer/tableView. aspx?ReportId=96 (all last visited on Feb. 6, 2018).

4. Hong Kong and Macau, the two special administrative regions of China, are independent from mainland China in terms of economy so that they are treated as separate economies in this paper. For more on the economic links between China and Hong Kong and between China and Macau, see Chun Kwok Lei \& Shujie Yao, Economic Convergence in Greater China: Mainland China, Hong Kong, Macau and Taiwan 7-9 (2008).

5. 'Korea' refers to South Korea in this paper.

6. Not all six economies are covered with the same weight in this paper. China is given special attention due to the largest size and the importance of its economy. In addition, some economies are not covered in parts of this paper due to a lack of available data.

7. UNCTAD, Global FDI Flows Declined in 2014. China Becomes the World's Top FDI Recipient, 18 Global Investment Trends Monitor 1 (2015), available at http://unctad.org/ en/PublicationsLibrary/webdiaeia2015d1_en.pdf (last visited on Feb. 6, 2018).

8. UNCTAD, supra note 2.

9. UNCTAD, Unctad Stat, available at http://unctadstat.unctad.org/wds/TableViewer/ tableView.aspx?ReportId=96740 (last visited on Feb. 6, 2018).

10. UNCTAD, supra note 2.

11. UNCTAD, supra note 9.

12. OECD, OECD.Stat, available at http://stats.oecd.org/Index.aspx?DataSetCode=FDI_ AGGR_SUMM (last visited on Feb. 6, 2018).

13. UNCTAD, supra note 9.

14. 'Investment treaty' in this paper refers to bilateral investment treaties ("BITs") and other types of investment agreements, such as free trade agreements and the Energy Charter 
Treaty. It is a general trend to include an investment chapter in free trade agreements.

15. 2,363 BITs and 310 treaties with investment provisions ("TIPs"). See UNCTAD, International Investment Agreements Navigator, available at http://investmentpolicyhub. unctad.org/IIA (last visited on Feb. 6, 2018).

16. Id.

17. Brazil signed fourteen BITs that were later withdrawn in 2002, apparently because treaty provisions for ISDS were unconstitutional. See S. Hawes, Trends in investment treaty arbitration: a perspective on Brazil, Thomson Reuters: Practical Law Arbitration Blog (Oct. 30, 2017), available at http://arbitrationblog.practicallaw.com/trends-in-investment-treatyarbitration-a-perspective-on-brazil (last visited on Feb. 6, 2018). None of the TIPs in force in Brazil provide for ISDS.

18. UNCTAD, supra note 2.

19. Id.

20. N. Gallagher, China's BIT's and Arbitration Practice: Progress and Problems, in ChInA and International Investment Law: Twenty Years of ICSID Membership 182 (Wenhua Shan ed., 2015).

21. Guiguo Wang, China's Practice in International Investment Law: From Participation to Leadership in the World Economy, 34 Yale J. InT'L L. 577 (2009).

22. Yongjie Li, Factors to be Considered for China's Future Investment Treaties, in Wenhua Shan ed., supra note 20, at 174.

23. Wang, supra note 21, at 577.

24. Shoushuang Li, The Legal Environment and Risks for Foreign Investment in China 113 (2007). Li also notes that large-scale nationalization will not occur in China unless governmental institutions undergo a fundamental political change.

25. S. Greenberg et al., International Commercial Arbitration: An Asia-Pacific Perspective 33 (2011).

26. Li Hu, Introduction to Commercial Arbitration in China, Software Info. Ctr. at 1 , available at http://www.softic.or.jp/symposium/open_materials/11th/en/LiHu.pdf (last visited on Jan. 1, 2018).

27. S. Ali, Arbitration in Asia in a Comparative Perspective: Examining the Role of the Arbitrator in Facilitating Settlement, in International Commercial Arbitration in Asia 20 (S. Ali \& T. Ginsburg eds., 2013).

28. T. Cole, Commercial Arbitration in Japan: Contributions to the Debate on Japanese 'NonLitigiousness', 40 N.Y.U. J. InT'L L. \& Pol. 39 (2007).

29. Hiroyuki Tezuka \& Yutaro Kawabata, Arbitration Guide [JAPAN], Int'1 Bar Ass'n (Feb. 2012), available at http://www.ibanet.org/Document/Default. aspx?DocumentUid=DBCF3CAB-E985-4A9B-BBA1-D8D9D191EF5E (last visited on Feb. 6, 2018). See also Tatsuya Nakamura \& L. Nottage, Arbitration in Japan, in Ali \& Ginsburg eds., supra note 27, at 223-7.

30. The Korean Commercial Arbitration Board ("KCAB") hears both domestic and international business disputes in Korea. However, it reported administering only 413 arbitration cases (339 domestic cases and 74 international cases) in 2013, although the $\mathrm{KCAB}$ is de facto the only arbitration institution in Korea, and more than 1 million civil 
lawsuits are brought to court in Korea each year. See KCAB, 2015 Annual Report, at 7, available at http://www.kcab.or.kr/jsp/comm_jsp/BasicDownload.jsp?FilePath=marketing/ f_0.83413551785897241463617259521\&orgName=Annual Report_2015.pdf (last visited on Feb. 6, 2018).

31. A. Lin \& N. Li, Arbitration in Taiwan, the Republic of China, in Ali \& Ginsburg eds., supra note 27, at 534-5.

32. Japan and Korea transformed their legal education systems and established US-style law school systems in 2004 and 2009, respectively. Prior to that, both featured highly selective national bar exams, which less than five percent of applicants typically passed.

33. Kim \& Chang, e.g., based in Korea and the largest Asian law group outside of China with more than 800 attorneys. It has only one overseas office in Hong Kong. Nishimura \& Asahi, Japan's largest law firm with more than 500 attorneys, did not begin to establish its overseas offices until June 2010.

34. G. Kim, East Asian Cultural Influences, in Asian Leading Arbitrators' Guide to International Arbitration 34-6 (M. Pryles \& M. Moser eds., 2007).

35. Professor An Chen, although he later resigned from both cases, was the first Chinese coarbitrator in two ICSID cases, Bernhard von Pezold and others v. Republic of Zimbabwe (ICSID Case No. ARB/10/15) and Border Timbers Limited, Timber Products International (Private) Limited, and Hangani Development Co. (Private) Limited v. Republic of Zimbabwe (ICSID Case No. ARB/10/25).

36. ICSID, Arbitrators, Conciliators and Ad Hoc Committee Members, available at https:// icsid.worldbank.org/en/Pages/arbitrators/CVSearch.aspx (last visited Feb. 6, 2018).

37. In 2011, Teresa Cheng, a Hong Kong-based arbitrator, was appointed president of the tribunal for Bawabet Al Kuwait Holding Company v. Arab Republic of Egypt. Professor Shin Hi-Taek was the first Korean ICSID arbitrator appointed in 2013 as the president of the tribunal for Fábrica de Vidrios Los Andes, C.A. and Owens-Illinois de Venezuela, C.A. v. Bolivarian Republic of Venezuela (ICSID Case No. ARB/12/21). Yasuhei Taniguchi is the only Japanese arbitrator to participate in ICSID cases and was appointed in 2013 as an ad hoc committee member by the chairman of the ICSID Administrative Council in the annulment proceeding of EDF International S.A., SAUR International S.A. and León Participaciones Argentinas S.A. v. Argentine Republic (ICSID Case No. ARB/03/23).

38. Administrative litigation commonly refers to lawsuits filed by individuals or companies against decisions of governments and governmental officials that allegedly infringe upon the rights and interests of the individuals or companies involved. In the common law system, the term 'judicial review' is used instead, which generally refers to review of governmental actions by the judiciary. See Yuwen Li \& Yun Ma, Introduction, in Administrative Litigation Systems in Greater China and Europe 1 (Yuwen Li ed., 2014).

39. Shotaro Hamamoto, Protection of the Investor's Legitimate Expectations: Intersection of a Treaty Obligation and a General Principle of Law, in China AND InTERNATIONAL Investment Law: Twenty Years of ICSID Membership 168 (Wenhua Shan \& Jinyuan Su eds., 2014).

40. T. Ginsburg, Dismantling the "Developmental State"? Administrative Procedure Reform in Japan and Korea, 49 Ам. J. СомP. L. 588 (2001). 
41. Ji Li, Suing the Leviathan - An Empirical Analysis of the Changing Rate of Administrative Litigation in China 10 J. Empirical Legal Stud. 819 (2013).

42. R. Peerenboom, More law, less courts: Legalized governance, judicialization, and dejudicialization in China, in Administrative Law and Governance in Asia: Comparative Perspectives 175-6 (T. Ginsburg \& A. Chen eds., 2009).

43. Hitoshi Ushijima, Administrative law and judicialized governance in Japan, in Ginsburg \& Chen, $i d$. at 81.

44. Katsuya Uga, Development of the Concepts of Transparency and Accountability in Japanese Administrative Law, in LAw In JAPAN: A TuRning PoInt 276, 299 (D. Foote ed., 2011).

45. Jongcheol Kim, Government reform, judicialization, and the development of public law in the Republic of Korea, in Ginsburg \& Chen, supra note 42, at 103.

46. E.g., Article 14 (1) of the Administrative Case Litigation Act of Japan (amended in 2007) states that no action to revoke an administrative disposition may be filed when a period of six months has elapsed from the day on which the person who seeks revocation became aware of the fact that the original administrative disposition or administrative disposition on appeal was made. However, this shall not apply if there are justifiable grounds for failing to meet the time limit. Article 20 (1) of the Korean Administrative Litigation Act has a similar provision, but it is even more restrictive and requires the plaintiff to initiate an action within ninety days from the date a disposition is made known to the plaintiff.

47. Jiunn-rong Yeh, Democracy-driven transformation to regulatory state: The case of Taiwan, in Ginsburg \& Chen, supra note 42, at 129.

48. First and second instance only. See R. Perlingeiro, Brazil's Administrative Justice System in a Comparative Context, 1 Revista de Investigações Constitucionais 58 (2014), available at $\mathrm{http} / / / \mathrm{www}$.academia.edu/4242554/Brazils_Administrative_Justice_System in_a_Comparative_Context (last visited on Feb. 6, 2018).

49. Ass'n of the Councils of State and Supreme Admin. Jurisdictions of the European Union [ACA-Eur.], Administrative Justice in Europe-Report for Sweden, at 17, available at http://www.aca-europe.eu/en/eurtour/eurtour_en2.lasso?page=detail\&countryid=24 (last visited on Feb. 6, 2018).

50. ACA-Eur., Administrative Justice in Europe-Report for Lithuania, at 38-40, available at http://www.aca-europe.eu/en/eurtour/eurtour_en2.lasso?page=detail\&countryid=16 (last visited on Feb. 6, 2018).

51. ACA-Eur., Administrative Justice in Europe-Report for Spain, at 20, available at http:// www.aca-europe.eu/en/eurtour/eurtour_en2.lasso?page=detail\&countryid=7 (last visited on Feb. 6, 2018).

52. A. Trochev, Suing Russia at Home, 59 Probs. Post-Communism 22 (2012) (in Russian Courts of General Jurisdiction and the Arbitrazh courts).

53. ACA-Eur., Administrative Justice in Europe-Report for France, at 29, available at http:// www.aca-europe.eu/en/eurtour/eurtour_en2.lasso?page=detail\&countryid=10 (last visited on Feb. 6, 2018).

54. ACA-Eur., Administrative Justice in Europe-Report for Poland, at 29-30, available at http://www.aca-europe.eu/en/eurtour/eurtour_en2.lasso?page=detail\&countryid=20 (last 
visited on Feb. 6, 2018).

55. Judicial Yuan [司法院], Judicial Statistics [司法統計], available at http://www.judicial. gov.tw/juds/ (last visited on Feb. 6, 2018).

56. Tribunais da RAEM [澳門特別行政區法院], Statistics [統計資料], available at http://www. court.gov.mo/zh/subpage/statisticsta (last visited on Feb. 6, 2018).

57. Court of Korea [대한민국 법원], Judicial Yearbook (Statistics) [사법연감(통계)], available at https://www.scourt.go.kr/portal/justicesta/JusticestaListAction.work?gubun=10 (last visited on Feb. 6, 2018).

58. Supreme People's Court of PRC [最高人民法院], National Judicial Statistics 2008 [2008年 全国法院司法统计公报], available at http://gongbao.court.gov.cn/Details/1387a39eb10a88 6fc87cafaa8ab26f.html (last visited on Feb. 6, 2018).

59. Court of Japan, Judicial Statistics [司法統計], available at http://www.courts.go.jp/app/ sihotokei_jp/search (last visited on Feb. 6, 2018).

60. First instance only. See B. Tai, Judicial Review of Administrative Actions, at 5 (The University of Hong Kong Faculty of Social Sciences ed., 2013), available at http://www. socsc.hku.hk/ExCEL3/event/ppt/btai.pdf (last visited on Feb. 6, 2018).

61. UNCTAD, Unctad Stat, available at http://unctadstat.unctad.org/wds/TableViewer/ tableView.aspx?ReportId=97 (last visited on Feb. 6, 2018).

62. A. Szamosszegi \& C. Kyle, An Analysis of State-Owned Enterprises and State Capitalism in China, U.S.-China Economic and Security Review Commission Report (Oct. 26, 2011), available at http://www.uscc.gov/sites/default/files/Research/10_26_11_ CapitalTradeSOEStudy.pdf (last visited on Feb. 6, 2018).

63. Id.

64. International Business Publications, Taiwan: How to Invest, Start and Run Profitable Business in Taiman Guide - Practical Information, Opportunities, Contacts 70 (2013).

65. Ali, supra note 27, at 14.

66. Id.

67. Id.

68. G. Kaufmann-Kohler \& Fan Kun, Integrating Mediation into Arbitration: Why it Works in China, 25 J. INT'L ARB. 480-1 (2008), available at http://www.arbitration-icca.org/ media/0/12319139722760/00951635.pdf (last visited on Feb. 6, 2018). This may be coupled with the improving - but still relatively uncertain - rule of law and the resultant distrust of the court system.

69. L. Nottage, Why No Investor-State Arbitration in the Australia-Japan FTA?, East Asia Forum, Apr. 9, 2014, available at http://www.eastasiaforum.org/2014/04/09/why-noinvestor-state-arbitration-in-the-australia-japan-fta (last visited on Feb. 6, 2018). For a social-cultural analysis of why arbitration has not been widely used in Japan, see Cole, supra note 28.

70. Zewei Yang, The Energy Charter Treaty and Dispute Settlement of Transnational Energy Pipelines: in a Chinese Perspective 19-20 (British Inst. of Int'l and Comparative Law, Event Paper, Sept. 19, 2008), available at https://www.biicl.org/files/3768_2a_-yang_ zewei.doc (last visited on Feb. 6, 2018).

71. Nottage, supra note 69. Currently, there are two ongoing ICSID cases initiated by Japanese 
investors: JGC Corporation v. Kingdom of Spain (ICSID Case No. ARB/15/27) and Eurus Energy Holdings Corporation and Eurus Energy Europe B.V. v. Kingdom of Spain (ICSID Case No. ARB/16/4).

72. Id.

73. (Shaun) Zhuang-Hui Wu, International Arbitration for Chinese-Foreign Disputes: Emerging Choices in 2012, 41 INT'L L. News 4 (2012), available at http://www. americanbar.org/content/dam/aba/publications/international_law_news/iln_spr12_reprint. authcheckdam.pdf (last visited on Feb. 6, 2018).

74. Kim, supra note 34, at 28-31.

75. PRC Ministry of Commerce (MOFCOM), 2009 Statistical Bulletin of China's Outward Foreign Direct Investment, at 18, available at http://images.mofcom.gov.cn/hzs/ accessory/201009/1284339524515.pdf (last visited on Feb. 6, 2018). Other types of companies, such as limited liability companies, account for the rest.

76. Ligang Song et al., State-Owned Enterprises' Outward Investment and the Structural Reform in China, 19 China \& World ECONOMY 39 (2011).

77. The Chinese government often holds a significant stake in non-SOE companies, as classified by the Chinese government, and thus exerts a considerable influence on them.

78. J. Knoerich, China's Outward Investment Surge, in World Scientific Reference on Globalisation in Eurasia and the Pacific Rim 290 (D. Dyker ed., 2015).

79. B. Gill \& J. Reilly, The Tenuous Hold of China Inc. in Africa, 30 WASH. Q. 38 (2007).

80. Id. at 38-9 \& 47-8.

81. $I d$. at 44 .

82. Id. at $48-9$.

83. J. Yackee, Do Bilateral Investment Treaties Promote Foreign Direct Investment? Some Hints from Alternative Evidence, 55 VA. J. INT'L L. 411 (2010).

84. Id.

85. ICSID, Advanced Search, available at, https://icsid.worldbank.org/en/Pages/cases/ searchcases.aspx (last visited on Feb. 6, 2018).

86. IBRD, Manufacturing, value added (\% of GDP), available at https://data.worldbank.org/ indicator/NV.IND.MANF.ZS (last visited on Feb. 6, 2018).

87. See Contribution of the industrial sector to overall GDP of Taiwan in 2016, by subsector, Statista, available at https:/www.statista.com/statistics/321603/taiwan-industrial-sectorgdp-proportion-by-subsector (last visited on Feb. 6, 2018).

88. R. van Hoesel, New Multinational Enterprises from Korea and Taiwan 106 (2013).

89. A. Megyeri et al., Taiwan's Outward Foreign Direct Investment (OFDI) into the European Union and Its Member States: Quantitative Research 11 (Eur. Inst. for Asian Stud. Report, Oct. 2014), available at https://www.roc-taiwan.org/public/SK_en_news/5110011671.pdf (last visited on Feb. 6, 2018).

90. OECD, FDI positions by industry, available at http://stats.oecd.org/Index. aspx?DataSetCode=FDI_POSITION_INDUSTRY (last visited on Feb. 6, 2018). Data on Latvia, Mexico, and New Zealand are not available for 2006; data on Belgium, Israel, Latvia, Mexico, and New Zealand are not available for 2010; and data on Finland and Mexico are not available for 2014. 
91. Jianping Zhang et al., A study on FDl's role in China's economic growth and development since China's reform and opening-up, in Foreign Direct Investments in Asia 226 (C. Sussangkam et al. eds., 2011).

92. UNCTAD, Bilateral FDI Statistics 2014, available at http://unctad.org/en/Pages/DIAE/ FDI\%20Statistics/FDI-Statistics-Bilateral.aspx (last visited on Feb. 6, 2018).

93. OECD, FDI positions by partner country, available at http://stats.oecd.org/Index. aspx?DataSetCode=FDI_POSITION_PARTNER (last visited on Feb. 6, 2018).

94. UNCTAD, supra note 9.

95. L.-C. Wolff, Approval and Registration Requirements, in China Outbound Investments: A Guide to Law and Practice 22 (L.-C. Wolff ed., 2011).

96. Id. Other goals of routing investment to China through Hong Kong include utilizing the Mainland and Hong Kong Closer Economic Partnership Arrangement or keeping investors' identities secret.

97. Wolff, supra note 95, at 22.

98. S. Poncet, Inward and Outward Investment in China, in China AND the World EConomy 115 (D. Greenaway et al. eds., 2010).

99. UnCtad, World Investment Report 2007: Transnational Corporations, Extractive Industries and Development 56 (2007), available at http://unctad.org/en/docs/wir2007_ en.pdf (last visited on Feb. 6, 2018).

100. United Nations Economic Commission for Africa, Economic Report on Africa 2006: Capital Flow and Development Financing in Africa 134 (2006), available at https:// www.uneca.org/sites/default/files/PublicationFiles/era2006full.pdf (last visited on Feb. 6, 2018).

101. MOFCOM, Statistics on FDI in China 2015 [中国外资统计 2015] 21 (2015), available at http://www.fdi.gov.cn/CorpSvc/Temp/T3/Product.aspx?idInfo=10000544\&idCorp=1800 000121 \&iproject $=33 \&$ record $=5481$ (last visited on Feb. 6, 2018).

102. OECD, FDI flows by industry, available at http://stats.oecd.org/Index. aspx?DatasetCode=FDI_FLOW_INDUSTRY (last visited on Feb. 6, 2018).

103. Zhang et al., supra note 91, at 231.

104. K. Liu, Foreign Direct Investment in China Manufacturing Industry-Transformation from a Low-Tech to High-Tech Manufacturing, 6 InT'L J. Bus. \& MGmt. 15 (2011).

105. See Taiwan: Foreign Investment, Santander Trade, available at https://en.portal. santandertrade.com/establish-overseas/taiwan/foreign-investment (last visited on Feb. 6, 2018).

106. MOFCOM, supra note 101, at 21.

107. Data on Finland, Mexico, and Portugal are not available.

108. OECD, supra note 90.

109. V. Bath, The quandary for Chinese regulators: Controlling the flow of investment into and out of China, in Foreign Investment and Dispute Resolution Law and Practice IN Asia 71 (V. Bath \& L. Nottage eds., 2011). The most recent one was promulgated in 2017, and previous amendments were made in 1997, 2002, 2004, 2007, 2011, and 2015. See Catalogue of Industries for Guiding Foreign Investment (2017) [外商投资产业指导 目录 (2017年修订)], Invest in China [中国投资指南], available at http://www.fdi.gov. 
cn/1800000121_39_4851_0_7.html (last visited on Feb. 6, 2018).

110. Investment in other industries is permitted.

111. MOFCOM Catalogue for the Guidance of Foreign Investment Industries (amended in 2011) [外商投资产业指导目录 (2011年修订)], available at http://english.mofcom.gov. cn/article/policyrelease/aaa/201203/20120308027837.shtml (last visited on Feb. 6, 2018). In practice, there are a number of cases in which foreign investors make investments in China via a nominal shareholder for various reasons, such as circumventing the industry restrictions of the Catalog, foreign exchange rules, government formalities, etc. See J. Tian, Legal issues regarding dormant investment by foreign investors in China, Sinoblawg.com, Nov. 11, 2011, available at http://www.sinoblawg.com/?p=228 (last visited on Feb. 6, 2018). In such cases, investors may not have a standing in investment arbitration.

112. ICSID, supra note 85.

113. S. Wacaster, The Mineral Industry of Japan, in U.S. Geological Survey Minerals Y.B. 2014 [advance release] 13.1 (2016), available at https://minerals.usgs.gov/minerals/pubs/ country/2014/myb3-2014-ja.pdf (last visited on Feb. 6, 2018).

114. HKSAR Census and Statistics Department, National Income, available at https://www. censtatd.gov.hk/hkstat/sub/sp250.jsp?tableID $=036 \& I D=0 \&$ productType $=8$ (last visited on Feb. 6, 2018).

115. S. Wacaster, The Mineral Industry of the Republic of Korea, in U.S. Geological Survey Minerals Y.B. 2014 [advance release] 15.1 (2016), available at https://minerals.usgs. gov/minerals/pubs/country/2014/myb3-2014-ks.pdf (last visited on Feb. 6, 2018).

116. Lin Shi, The Mineral Industry of Taiwan, in U.S. Geological Survey Minerals Y. B. 2014 [advance release] 25.1 (2016), available at https://minerals.usgs.gov/minerals/pubs/ country/2014/myb3-2014-tw.pdf (last visited on Feb. 6, 2018).

117. J. Givens, On their best behavior: foreign plaintiffs in Chinese administrative litigation, Jan. 1, 2012, at 35, available at https://ssrn.com/abstract=2169379 (last visited on Feb. 6, 2018)

118. Id. at 9 .

119. M. Santoro, China 2020: How Western Business Can - and Should - Influence Social and Political Change in the Coming Decade 113 (2015).

120. Id.

121. Yadong Luo, GuAnXI And Business $194-8$ \& 206-8 (2007).

122. P. Norton, Informal Dispute Settlement Approaches, in Managing Business Disputes in Today's China: Dueluing with Dragons 21 (M. Moser ed., 2007).

123. Id.

124. SANTORO, supra note 119, at 114.

125. See Japan looks to more than double investment treaty partners by 2020, NIKKEI ASIAN Rev., May 11, 2016, available at https://asia.nikkei.com/Politics-Economy/InternationalRelations/Japan-looks-to-more-than-double-investment-treaty-partners-by-2020 (last visited on Feb. 6, 2018).

126. Hinrich Voss, The Determinants of Chinese Outward Direct Investment 94 (2011).

127. UNCTAD, supra note 9. 
128. Wu, supra note 73, at 8. In Korea, ISDS emerged as such a hot political issue in 2011.

129. A. Osman, China's Maritime Silk Road and the Future of African Arbitration, 3 Transnat'l Dispute Mgmt. (2017), available at http://www.transnational-disputemanagement.com/article.asp?key=2485 (last visited on Feb. 6, 2018).

130. Jingwen Zhu, Data Analysis of Professionalization of Legal Workers in China, 9 Frontiers L. China 277 (2014), available at http://journal.hep.com.cn/flc/EN/10.3868/ s050-003-014-0016-2 (last visited on Feb. 6, 2018).

131. The number of arbitration cases reached 113,660 in 2014. See H. Chen, Arbitration in China - A Brief Report on Recent Developments, Expert Guides, Sept. 30, 2015, available at https://www.expertguides.com/articles/arbitration-in-china-a-brief-report-on-recentdevelopments/arcozafw (last visited on Feb. 6, 2018).

132. Nakamura \& Nottage, supra note 29, at 225. See also B. Hughes \& T. Walsh, Recent Developments in South Korea, Expert Guides, Jan. 9, 2014, available at ttps://www. expertguides.com/articles/recent-developments-in-south-korea/re5709da (last visited on Feb. 6, 2018).

133. Vis East Moot, About, available at http://www.cisgmoot.org/en-US/content/8193 (last visited on Feb. 6, 2018).

134. Foreign Direct Investment Moot, Foreign Direct Investment International Arbitration Moot Regionals, available at http://www.fdimoot.org/regionals.php (last visited on Feb. 6, 2018).

135. RISS, Korea Education and Research Information Survey, available at http://www.riss.kr (searched with the keyword “국제투자중재") (last visited Feb. 6, 2018).

136. Shuming Zhao \& Juan Du, The Changing Nature of Management and Culture in China, in Managing Across Diverse Cultures in East Asia: Issues and Challenges in A Changing Globalized World 80 (M. Warner ed., 2013).

137. M. Powell, Human resource management practices in Japan: Are they really changing?, 2 Merici 86 (2016), available at http://press-files.anu.edu.au/downloads/press/n2328/pdf/ ch09.pdf (last visited on Feb. 6, 2018).

138. Heungsik Park, Administrative Culture, in Public Administration and Policy in Korea: Its Evolution and Challenges 153 (Keun Namkoong et al. eds., 2017).

139. Huichun Yu \& P. Miller, The generation gap and cultural influence: a Taiwan empirical investigation, 10 Cross Cultural Mgmt.: Int'L J. 26 (2003).

140. G:HUB, China's Outward Foreign Direct Investment in 2013, available at http://www. ghub.org/cfc_en/wp-content/uploads/sites/2/2014/10/2014.10.11-OFDI-Stats-AlertUpdate.pdf (last visited on Feb. 6, 2018).

141. Wei Tian \& Ding Qingfen, Private Investors Play Bigger Role Overseas, CHINA DAILY, Aug. 31, 2012, available at http://usa.chinadaily.com.cn/business/2012-08/31/ content_15722435.htm (last visited on Feb. 6, 2018).

142. Laney Zhang, China: Catalog of Foreign Investment Industries Updated, Library of Congress Global Legal Monitor (Aug. 7, 2017), available at http://www.loc.gov/law/ foreign-news/article/china-catalog-of-foreign-investment-industries-updated (last visited on Feb. 6, 2018).

143. See China foreign investment: New catalogue revises which industries are accessible to overseas 
investors, Norton Rose Fulbright (July 2015), available at http://www.nortonrosefulbright. $\mathrm{com} /$ knowledge/publications/130091/china-foreign-investment-new-catalogue-revises-whichindustries-are-accessible-to-overseas-investors (last visited on Feb. 6, 2018).

144. According to data from UNCTAD, 102 out of 817 known cases were based on the Energy Charter Treaty. The second most frequently invoked treaty was NAFTA, which was invoked in 59 cases. See UNCTAD, Investment Policy Hub, available at http:// investmentpolicyhub.unctad.org/ISDS/FilterByApplicableIia (last visited on Feb. 6, 2018).

145. N. Bernasconi-Osterwalder, Expansion of the Energy Charter to Africa and Asia: Undoing Reform in International Investment Law?, 8 Inv. Treaty News 3-6 (2017).

146. A. Florini, Energy: A Fundamental Transformation?, in Beyond Gridlock 108 (T. Hale \& D. Held eds., 2017).

147. Tsuyoshi Inajima \& Emi Urabe, As \$21 Billion Gas Market Opens, Japan Seeks Strength in Numbers, Bloomberg, Jan. 17, 2017, available at https://www.bloomberg.com/news/ articles/2017-01-18/as-21-billion-gas-market-opens-japan-seeks-strength-in-numbers (last visited on Feb. 6, 2018).

148. H. Broadman \& Xiaolun Sun, The distribution of foreign direct investment in China 15 (World Bank Policy Research Working Paper No. WPS 1720, 1997), available at http:// documents.worldbank.org/curated/en/236351468770439451/pdf/multi-page.pdf (last visited on Feb. 6, 2018).

149. M. Noland et al., Developing the Service Sector as Engine of Growth for Asia: An Overview 1 (ADB Economics Working Paper No. 320, 2012), available at https://www. adb.org/sites/default/files/publication/30080/economics-wp320.pdf (last visited on Feb. 6, 2018).

150. Id.

151. Yanrui Wu, China's services sector: the new engine of economic growth, 56 EURASIAN GeoFigurey And EConomics 618 (2016).

152. Iris Jin \& Xiaogang Li, China's Inward FDI Flowing to Service and Advanced Manufacturing Sectors, APF Canada blog (June 27, 2016), available at https://www. asiapacific.ca/blog/chinas-inward-fdi-flowing-service-and-advanced-manufacturing (last visited on Feb. 6, 2018).

153. Id.

154. Id.

155. Fukao Kyoji, Service Sector Productivity in Japan: The key to future economic growth (Introduction) (Research Institute of Economy, Trade and Industry, Policy Discussion Paper No. 10-P-007, 2010), available at https://www.rieti.go.jp/jp/publications/ pdp/10p007.pdf (last visited on Feb. 6, 2018).

156. Thanh Hoan Phan \& Ji Young Jeong, The development of Korea's service industry from a global historical perspective, 16 InT'L ArEa Stud. Rev. 184 (2013).

157. G. Veeck et al., China's Geography: Globalization and the Dynamics of Political, EConomic, and Social Change 359 (2011).

158. MOFCOM, Statistics on FDI in China [中国外资统计], available at http://www.fdi.gov. cn/1800000121_10000506_8.html (last visited on Feb. 6, 2018). 
